\title{
ROBERT KULSKI
}

ORCID: 0000-0003-3967-3985

Uniwersytet Łódzki

\section{NARUSZENIE PRZEPISÓW O NAGRYWANIU CZYNNOŚCI KOMORNIKA SĄDOWEGO JAKO PRZEWINIENIE DYSCYPLINARNE}

\begin{abstract}
Abstrakt: W artykule w pierwszej kolejności przeprowadzono analizę ważkich aspektów utrwalania przebiegu czynności komornika za pomocą urządzenia rejestrującego obraz i dźwięk (art. $809^{1}$ k.p.c.). Następnie przeprowadzono ocenę tego, czy naruszenie przepisów o nagrywaniu czynności komornika stanowi przewinienie dyscyplinarne. Według art. 222 pkt 11 u.k.s. komornik odpowiada dyscyplinarnie za inną niż wymienione w tym przepisie rażącą lub uporczywą obrazę przepisów prawa. Ocena ta musi być dokonywana z uwzględnieniem całokształtu okoliczności konkretnej sprawy. Generalnie rzecz ujmując, nie wydaje się, żeby naruszenie przez komornika przepisów o utrwalaniu przebiegu czynności dokonywanej z jego udziałem stanowiło rażącą obrazę przepisów prawa. Nie można jednak wykluczyć przypisania komornikowi uporczywej obrazy prawa, jeśli do naruszenia przepisów o utrwalaniu przebiegu czynności będzie dochodzić wielokrotnie, przez dłuższy okres czasu, z nastawieniem złej woli nieprzestrzegania tych przepisów.
\end{abstract}

Słowa kluczowe: nagrywanie czynności komornika, przewinienie dyscyplinarne, rażące naruszenie prawa, urządzenie rejestrujące obraz i dźwięk

Według przepisu art. 222 ab initio ustawy z dnia 28 marca 2018 roku o komornikach sądowych ${ }^{1}$ (dalej: u.k.s.) komornik odpowiada dyscyplinarnie za zawinione działania lub zaniechania (przewinienia dyscyplinarne). Jednocześnie przepis ten określa katalog przewinień dyscyplinarnych komorników ${ }^{2}$, w którego ramach należy rozróżnić przewinienia obejmujące naruszenie powagi lub godności urzędu albo inne uchybienie zasadom etyki zawodowej (art. 222 pkt 1 u.k.s.) oraz prze-

1 Tekst jedn. Dz.U. z 2021 r. poz. 850 ze zm.

2 Por. M. Dziewulska, [w:] Ustawa o komornikach sądowych. Komentarz, red. G. Sikorski, Sopot 2019, s. 663-664; M. Klonowski, [w:] Ustawa o komornikach sadowych. Ustawa o kosztach komorniczych. Komentarz, red. R. Reiwer, Warszawa 2019, uwagi do art. 222; M. ŚwieczkowskaWójcikowska, [w:] Ustawa o komornikach sadowych. Ustawa o kosztach komorniczych. Kodeks Etyki Zawodowej Komornika Sąowego. Komentarz, red. M. Świeczkowska-Wójcikowska, J. Świeczkowski, Warszawa 2020, uwagi do art. 222. 
winienia polegające na naruszeniu (obrazie) przepisów prawa wyszczególnione w art. 222 pkt $2-11$ u.k.s. ${ }^{3}$ Warto podkreślić, że wśród przewinień dyscyplinarnych $\mathrm{z}$ art. 222 u.k.s. znalazły się przewinienia, które zostały opisane przy użyciu zwrotów niedookreślonych i nieścisłych, co budzi istotne zastrzeżenia. Takie zwroty można dostrzec w punktach pierwszym (,,inne uchybienie zasadom etyki zawodowej”), czwartym (,podejmowanie czynności z nieuzasadnioną zwłoką”) czy jedenastym („rażąca lub uporczywa obraza przepisów”) tego przepisu.

Posłużenie się przy definiowaniu przewinień dyscyplinarnych zwrotami o charakterze nieprecyzyjnym ogranicza określenie wyraźnych granic odpowiedzialności dyscyplinarnej komorników sądowych. W rezultacie regulacja $\mathrm{z}$ art. 222 u.k.s. nie daje podstaw do stwierdzenia, że komornik może być pociągnięty do odpowiedzialności dyscyplinarnej za zawinione działania lub zaniechania ściśle (precyzyjnie) określone. Znaczący wpływ na sformułowanie takiego wniosku ma brzmienie przepisu art. 222 pkt 11 u.k.s., z którego wynika, że komornik odpowiada dyscyplinarnie za inną niż wymienione w pkt 1-10 rażącą lub uporczywą obrazę przepisów prawa. Zdaje się, że przyczyną decydującą o wprowadzeniu zwrotów nieostrych do tekstu tego przepisu był zamiar zindywidualizowanego uwarunkowania decyzji w przedmiocie przewinienia dyscyplinarnego. To zarazem oznacza, że wypełnienia takich zwrotów treścią powinien dokonać organ, który ocenia te właśnie okoliczności w konkretnej sprawie (in casu). Dotychczasowe uwagi dają pretekst do poddania ocenie, czy naruszenie przepisów o nagrywaniu czynności komornika stanowi przewinienie dyscyplinarne, o którym mowa w art. 222 pkt 11 u.k.s. Ocenę tę należy rozpocząć od gębszej analizy ważkich aspektów utrwalania przebiegu czynności komornika za pomocą urządzenia rejestrującego obraz i dźwięk.

Nagrywanie przebiegu czynności komornika jest uregulowane w art. $809^{1}$ k.p.c. Przepis ten został dodany do k.p.c. mocą ustawy z dnia 22 marca 2018 roku o komornikach sądowych i obowiązuje od dnia 1 stycznia 2019 roku. Należy również odnotować, że do tego przepisu został wydany akt wykonawczy, a mianowicie rozporządzenie Ministra Sprawiedliwości z 14 grudnia 2018 roku w sprawie zapisu obrazu i dźwięku z przebiegu czynności komornika sądowego (dalej: rozp. z.o.dź. $)^{4}$. Rozporządzenie to określa:

1. rodzaje urządzeń i środków technicznych służących do utrwalania obrazu i dźwięku z przebiegu czynności komornika sądowego,

2. sposób przechowywania, odtwarzania i kopiowania zapisów obrazu i dźwięku z przebiegu czynności komornika,

3. sposób zapoznania się z zapisem.

3 Więcej na temat odpowiedzialności dyscyplinarnej komorników sądowych zob. w szczególności P. Rączka, Odpowiedzialność dyscyplinarna komornika sądowego, „Przegląd Prawa Egzekucyjnego" 2006, nr 12, s. 89 n. i J. Jagieła, Odpowiedzialność dyscyplinarna komorników, asesorów i aplikantów komorniczych, [w:] Założenia projektu nowej ustawy o komornikach sądowych, red. A. Marciniak, Sopot 2013, s. 107.

4 Dz.U. z 2018 r. poz. 2449. 
W świetle art. $809^{1}$ k.p.c. należy rozróżnić utrwalanie przebiegu czynności obligatoryjne z urzędu (art. $809^{1} \S 1$ k.p.c.) i utrwalanie obligatoryjne na wniosek (art. $809^{1} \S 2$ k.p.c.).

Utrwalaniu obligatoryjnemu z urzędu podlega przebieg czynności egzekucyjnych dokonywanych przez komornika poza kancelarią, enumeratywnie wymienionych $\mathrm{w}$ art. $809^{1} \S 1$ k.p.c. Według tego przepisu utrwalaniu za pomocą urządzenia rejestrującego obraz i dźwięk podlega przebieg następujących czynności egzekucyjnych dokonywanych przez komornika poza kancelarią:

1. z udziałem dłużnika zmierzające do ustalenia jego stanu majątkowego;

2. zajęcie ruchomości;

3. wykonanie postanowienia o oddaniu ruchomości pod dozór innej osobie niż dłużnik;

4. licytacja ruchomości z wyłączeniem licytacji elektronicznej;

5. licytacja nieruchomości, chyba że jej przebieg jest utrwalany w sposób określony w art. $972 \S 2$;

6. oględziny nieruchomości;

7. wprowadzenie w zarząd nieruchomości w trybie art. 933;

8. opróżnienie pomieszczeń z osób lub rzeczy;

9. wydanie ruchomości i nieruchomości;

10. wprowadzenie w posiadanie;

11. przymusowe otwarcie pomieszczenia;

12. przeszukanie mieszkania lub pomieszczenia gospodarczego dłużnika.

Zaznaczmy, że utrwalanie zajęcia ruchomości za pomocą urządzenia rejestrującego obraz i dźwięk (art. $809^{1} \S 1$ pkt 2 k.p.c.) nie powoduje, że komornik jest zwolniony od wpisania ruchomości do protokołu zajęcia. Jak bowiem wynika $\mathrm{z}$ art. $847 \S 1$ k.p.c. przez wpisanie ruchomości do tego protokołu komornik dokonuje zajęcia.

Co się tyczy licytacji zajętej nieruchomości (art. $809^{1} \S 1$ pkt 5 k.p.c.), jej przebieg jest utrwalany przez komornika tylko wtedy, gdy czynność ta nie jest utrwalana przez sąd w trybie art. $972 \S 2$ k.p.c. Jeżeli więc z jakichkolwiek przyczyn (na przykład braku odpowiedniego urządzenia) sąd nie będzie utrwalać przebiegu licytacji nieruchomości za pomocą urządzenia rejestrującego obraz i dźwięk, zobowiązany do nagrywania jej przebiegu jest komornik. Obowiązek ten nie będzie go obciążać, jeśli sąd zdecyduje się utrwalać przebieg licytacji nieruchomości za pomocą urządzenia rejestrującego wyłącznie dźwięk ${ }^{5}$. Przed rozpoczęciem licytacji komornik powinien ustalić, który organ egzekucyjny będzie utrwalać jej

5 Wprawdzie utrwalanie przebiegu licytacji przez sąd wyklucza obowiązek utrwalania licytacji przez komornika, jednak nie zwalnia to tego ostatniego od sporządzenia protokołu, który może mieć postać uproszczoną. A.J. Szereda, Egzekucja z nieruchomości po zmianach wprowadzonych ustawa o komornikach sqdowych, [w:] Analiza i ocena ustawy o komornikach sądowych oraz ustawy o kosztach komorniczych, red. A. Marciniak, Sopot 2018, s. 663 n.; A. Marciniak, Sadowe postępowanie egzekucyjne w sprawach cywilnych, Warszawa 2019, s. 413-414. 
przebieg. Ponieważ licytacja nieruchomości nie odbywa się na posiedzeniu sądu, nie ma podstaw do sporządzania protokołu licytacji przez sąd na zasadach określonych w art. 157 k.p.c. w zw. $\mathrm{z}$ art. 13 § 2 k.p.c.

$\mathrm{Na}$ wniosek strony możliwe jest utrwalenie przebiegu czynności innych niż te wymienione w art. $809^{1} \S 1$ k.p.c. Mogą być wśród nich nie tylko czynności egzekucyjne, lecz także nieegzekucyjne, przy czym chodzi zawsze o czynności, które są dokonywane przez komornika poza kancelarią.

Wniosek o utrwalanie przebiegu czynności innej niż te wymienione w art. $809^{1}$ $\S 1$ k.p.c. ma charakter konstytutywny w tym znaczeniu, że jest warunkiem nagrania czynności przez komornika ${ }^{6}$. Bez takiego wniosku organ egzekucyjny nie może utrwalać przebiegu tej czynności, co oznacza niemożność nagrania jej przebiegu z urzędu. Utrwalanie przebiegu czynności na wniosek strony wywołuje takie same skutki, jak utrwalanie przebiegu czynności wymienionych w art. $809^{1} \S 1$ k.p.c.

Wniosek może złożyć jedynie strona postępowania egzekucyjnego, a więc dłużnik lub wierzyciel. Jeżeli po stronie dłużnika występuje współuczestnictwo, wniosek o nagrywanie czynności komornika złożony przez jednego z dłużników (na przykład małżonka przy egzekucji z majątku wspólnego) jest skuteczny wobec dłużnika niedziałającego. Należy podkreślić, że w wypadku współuczestnictwa po stronie wierzyciela każdy z wierzycieli egzekwujących ma w postępowaniu egzekucyjnym w zasadzie te same prawa. Skuteczność czynności wierzycieli działających wobec wierzycieli niedziałających zależy zasadniczo od charakteru tych czynności oraz więzi materialnoprawnych łączących poszczególnych wierzycieli ${ }^{7}$. Biorąc pod uwagę cel, któremu służy nagrywanie czynności komornika, należy stwierdzić, że wniosek jednego z wierzycieli o utrwalanie przebiegu czynności jest skuteczny wobec wierzycieli niedziałających. Legitymacji do złożenia wniosku nie mają natomiast inni uczestnicy postępowania (na przykład osoby uczestniczące w przetargu przy egzekucji z ruchomości oraz z nieruchomości, nabywca ruchomości lub nieruchomości, dozorca zajętych ruchomości, o ile nie jest on dłużnikiem ani wierzycielem).

Wniosek o utrwalanie przebiegu czynności może być złożony na piśmie lub ustnie do protokołu i nie musi być uzasadniony. Nic nie stoi na przeszkodzie, żeby złożyć wniosek, o którym mowa, również w trakcie dokonywania czynności.

Utrwalaniu podlega przebieg czynności, a zatem według definicji słownikowej odbywanie się czynności, jej postęp w czasie i sposób, w jaki przebiega ${ }^{8}$. Nagrywanie czynności w trybie art. $809^{1}$ k.p.c. jest dokonywane wyłącznie za pomocą urządzenia rejestrującego obraz i dźwięk. Zgodnie z treścią $§ 2$ ust. 1 rozp.

6 Według M. Mulińskiego (Kodeks postępowania cywilnego. Komentarz do zmian, t. 2, red. T. Zembrzuski, Warszawa 2020, s. 1526) użyte w art. $809^{1} \S 2$ in initio k.p.c. słowo „utrwala” wskazuje, że wniosek strony jest wiążący dla komornika, chyba że w jego ocenie byłoby to sprzeczne z innymi przepisami rangi ustawowej, a w szczególności — rangi konstytucyjnej.

7 A. Marciniak, op. cit., s. 128-129.

8 Przebieg, [hasło w:] Słownik języka polskiego, https://sjp.pwn.pl/slowniki/przebieg.html. 
z.o.dź. zapis sporządza się za pomocą przenośnych urządzeń i środków technicznych wykorzystujących technikę cyfrową, które pozwalają na utrwalenie tego zapisu na informatycznym nośniku danych. Urządzenia, środki techniczne i informatyczne nośniki danych zapewniają możliwość kopiowania zapisu, zabezpieczenia go, w szczególności przed przypadkową utratą lub nieuzasadnioną zmianą, odtworzenie i udostępnianie (§ 2 ust. 2 rozp. z.o.dź.). Przebieg czynności utrwala komornik. Za dopuszczalne należy uznać utrwalanie przebiegu czynności przez pracownika kancelarii komorniczej.

Utrwalenie przebiegu czynności egzekucyjnej za pomocą urządzenia rejestrującego obraz i dźwięk nie może zastąpić sporządzenia protokołuํ. Niezależnie od nagrywania czynności egzekucyjnej komornik stwierdza tę czynność protokołem, przy czym w tym wypadku dokument ten ma formę skróconą. W protokole zamieszcza się oznaczenie miejsca i czasu czynności, imiona i nazwiska stron oraz innych osób uczestniczących w czynności, a także (jedynie) zwięzłe sprawozdanie z przebiegu czynności, wnioski i oświadczenia obecnych, wzmiankę o odczytaniu protokołu, podpisy obecnych lub wzmiankę o przyczynie braku podpisu i podpis komornika (art. $809^{1} \S 4$ zd. 1 k.p.c.). Należy jednak podkreślić, że z zajęcia mimo, że jest ono utrwalane za pomocą urządzenia rejestrującego obraz i dźwięk — sporządza się pełny protokół (art. $809^{1} \S 4$ zd. 2 k.p.c.), a nie jego skróconą wersję, o której mowa w art. $809^{1} \S 4$ zd. 1 k.p.c. Zapis obrazu i dźwięku dokonany w trybie art. $809^{1}$ k.p.c. jest dodatkowym sposobem utrwalenia przebiegu czynności egzekucyjnych i występuje obok protokołu pisemnego sporządzonego z mocy art. 809 k.p.c., w którym zamieszcza się wówczas, poza niektórymi elementami tego protokołu, zwięzłe sprawozdanie z przebiegu czynności (por. art. 809 i $809^{1} \S 4$ k.p.c.). W tym miejscu warto zaznaczyć, że wprawdzie protokołem, o którym mowa w art. 809 k.p.c., stwierdza się czynność egzekucyjną, jednak zaprotokołowanie również niektórych innych czynności dokonywanych w postępowaniu egzekucyjnym może być celowe, a niekiedy nawet konieczne. Jak bowiem wynika z art. 4 in fine u.k.s., przepis art. 809 k.p.c. ma odpowiednie zastosowanie do protokołu stanu faktycznego.

Na podstawie art. 15 ust. 3 ustawy z dnia 28 lutego 2018 roku o kosztach komorniczych ${ }^{10}$ (dalej: u.k.k.) komornikowi, który podejmuje czynności poza siedzibą kancelarii i utrwala ich przebieg w sposób przewidziany w art. $809^{1}$ k.p.c., należy się zryczałtowany zwrot kosztów związanych z utrwalaniem oraz przechowywaniem zapisu obrazu i dźwięku w wysokości 50 złotych, niezależnie od liczby czynności i gabarytu danych utrwalonych w sprawie. Zaznaczmy, że przytoczony

9 Zob. także M. Łochowski, [w:] Kodeks postępowania cywilnego. Komentarz, red. T. Szanciło, t. 2, 2019, uwaga nr 1 do art. $809^{1}$ k.p.c.

10 Tekst jedn. Dz.U. z 2021 r. poz. 210 ze zm. 
przepis ma zastosowanie niezależnie od tego, czy utrwalanie przebiegu czynności jest dokonywane z urzędu czy też na wniosek ${ }^{11}$.

W wypadku utrwalania przebiegu czynności egzekucyjnej z urzędu komornik nie powinien żądać (na przykład od wierzyciela, który wniósł we wniosku o wszczęcie egzekucji o zajęcie ruchomości) uiszczenia zaliczki w wysokości odpowiadającej kwocie zryczałtowanych kosztów utrwalania i przechowywania zapisu, to jest $50 \mathrm{z}^{12}$. Nie upoważnia go do tego przepis art. 7 ust. 1 u.k.k., który stanowi, że jeżeli czynność komornika powoduje wydatki, komornik uzależnia dokonanie tej czynności od uiszczenia zaliczki przez stronę, która wnosi o dokonanie czynności. Przytoczony przepis dotyczy czynności komornika powodującej wydatki, którą organ ten dokonuje na wniosek, w analizowanym wypadku chodzi zaś o nagrywanie czynności, które jest dokonywane przez komornika obligatoryjnie z urzędu. Nie oznacza to jednak, że w tym wypadku komornikowi kwota $50 \mathrm{zl}$ w ogóle się nie należy.

Inaczej przedstawia się natomiast uiszczenie zaliczki, jeśli utrwalanie przebiegu czynności następuje na wniosek. Wówczas komornik powinien zażądać zaliczki od wnioskodawcy w wysokości równej zryczałtowanym kosztom, o której mowa $\mathrm{w}$ art. 15 ust. 3 u.k.k. Jeżeli zaliczka nie zostanie natychmiast uiszczona, komornik dokonuje czynności, ale bez utrwalania jej przebiegu, o co wnosił wnioskodawca. Należy zatem podkreślić, że ściśle rzecz biorąc, w razie nieotrzymania

11 Por. także art. 6 pkt 5 u.k.k. Według tego przepisu, wydatkami są zryczałtowane koszty utrwalania czynności odbywających się poza kancelarią oraz przechowywania zapisu obrazu i dźwięku, o ile wierzyciel domagał się utrwalenia czynności. Przepis ten stanowi o wydatku w postaci zryczałtowanych kosztów utrwalania przebiegu czynności dokonywanego jedynie na wniosek wierzyciela. Wobec treści art. 15 ust. 3 u.k.k., przepis art. 6 pkt 5 u.k.k. nie ma większego znaczenia prawnego. Odmienne stanowisko co do relacji wymienionych przepisów ustawy o kosztach komorniczych zajmuje A. Laskowska-Hulisz. Według tej autorki do wydatków w rozumieniu art. 6 pkt 5 u.k.k. należą jedynie koszty związane z utrwalaniem czynności na wniosek wierzyciela. Katalog wydatków jest zamknięty, natomiast zgodnie z treścią art. 1 u.k.k., komornikowi przysługuje zwrot wydatków w zakresie określonym ustawą. Ustawa do katalogu wydatków nie zalicza zaś utrwalenia czynności dokonywanego z urzędu lub na wniosek dłużnika. Jeżeli zatem komornik utrwala czynność na wniosek dłużnika lub z urzędu, koszty jej utrwalenia, a następnie przechowywania, stanowią koszty działalności komornika i nie podlegają zwrotowi. A. Laskowska-Hulisz, Wydatki komornika sadowego i zasady ich ustalania w świetle ustawy o kosztach komorniczych, [w:] Komornicy sadowi i egzekucja w nowej rzeczywistości prawnej, red. R. Kulski, Sopot 2019, s. 196-197.

12 Do takiego wniosku zdaje się przychylać A. Laskowska-Hulisz, op. cit., s. 195-196. Natomiast inaczej P. Dzienis, [w:] Ustawa o komornikach sadowych. Ustawa o kosztach komorniczych. Komentarz, red. R. Reiwer, Warszawa 2019, komentarz do art. 15 u.k.k., zdaniem którego jeśli wierzyciel wnosi o przeprowadzenie czynności egzekucyjnej, podlegającej zgodnie $\mathrm{z}$ art. $809^{1} \S 1$ k.p.c. utrwalaniu, to tym samym składa wniosek o jej utrwalenie i istnieje podstawa do pobrania przez komornika zryczałtowanych wydatków. Wierzyciel jest bowiem świadomy, że złożenie wniosku o przeprowadzenie czynności egzekucyjnej wymienionej w katalogu zamieszczonym w art. $809^{1} \S 1$ k.p.c. powoduje obligatoryjne utrwalanie czynności. Wniosek o przeprowadzenie czynności podlegającej obligatoryjnemu utrwalaniu zawiera w sobie zgodę na jej utrwalenie, a w konsekwencji — pobranie zaliczki na wydatki z tym związane. 
zaliczki komornik nie może dokonać jedynie utrwalenia przebiegu czynności. Zaliczka i wniosek nie dotyczą natomiast dokonania samej czynności komornika ${ }^{13}$.

Według Ireneusza Kunickiego, mimo niezbyt jasnego sformułowania art. 15 ust. 3 u.k.k., należy uznać, że zwrot wydatku w kwocie 50 zł przysługuje komornikowi w danej sprawie egzekucyjnej. Nie ma zaś znaczenia, ile czynności komornik utrwalał przy jednorazowym wyjściu poza kancelarię, ani czy utrwalanie innych czynności w danej sprawie miało miejsce w kolejnych dniach ${ }^{14}$. Kwota 50 zł obejmuje także przechowywanie zapisu obrazu i dźwięku, a zatem za samo przechowywanie utrwalonego zapisu nie należy się zwrot kosztów.

Przejdźmy teraz do analizy zagadnień wyłaniających się na tle wykładni art. $809^{1} \S 3$ k.p.c. Jak wynika $\mathrm{z}$ art. $809^{1} \S 3$ zd. 1 k.p.c., komornik uprzedza osoby uczestniczące w czynności o utrwalaniu jej przebiegu zarówno wtedy, gdy utrwalanie ma miejsce z urzędu, jak i na wniosek. Stosownie do treści art. $809^{1}$ $\S 3$ zd. 2 i 3 k.p.c. komornik przerywa utrwalanie przebiegu czynności w miejscu zamieszkania dłużnika lub osoby trzeciej, jeżeli dłużnik lub ta osoba sprzeciwiają się temu, o czym należy te osoby pouczyć. Na żądanie osoby, która sprzeciwiła się utrwalaniu czynności, komornik podejmuje utrwalanie czynności na nowo, o czym należy te osoby pouczyć.

$\mathrm{Na}$ wstępie należy poczynić dwa zastrzeżenia. Po pierwsze utrwalanie przebiegu czynności w miejscu zamieszkania dłużnika lub osoby trzeciej jest obligatoryjne $\mathrm{z}$ urzędu w wypadkach, o których mowa w art. $809^{1} \S 1$ k.p.c., i na wniosek, o ile nie sprzeciwi się temu dłużnik lub osoba trzecia. Po drugie utrwalanie przebiegu czynności na nowo należy rozumieć jako kontynuowanie nagrania od chwili złożenia takiego żądania, nie jest natomiast konieczne przeprowadzenie utrwalanej czynności od początku.

Jak wynika z treści art. $809^{1} \S 3$ ab initio k.p.c., w każdym wypadku nagrywania czynności komornik uprzedza osoby uczestniczące w tej czynności o utrwalaniu jej przebiegu. Przez osoby te, na tle tego przepisu, należy rozumieć obecnych zarówno w trakcie, jak i w miejscu dokonywania czynności, której przebieg ma zostać utrwalony. Znaczenie tego sformułowania jest szerokie i obejmuje nie tylko uczestników postępowania egzekucyjnego według przepisów k.p.c. (na przykład przy postępowaniu egzekucyjnym z ruchomości nie będzie chodzić wyłącznie o wierzyciela, dłużnika, osobę trzecią, w której władaniu znajdują się ruchomości dłużnika).

W świetle przepisu art. $809^{1} \S 3$ zd. 2 i 3 k.p.c. istotne wątpliwości dotyczą chronologii czynności określonych w tym fragmencie. Jego brzmienie można rozumieć bądź w ten sposób, że komornik najpierw poucza osoby, o których tam mowa, a następnie rozpoczyna nagrywanie, bądź też, że komornik powinien je pouczyć już po rozpoczęciu utrwalania przebiegu czynności. Zdaje się, że pierwsza interpretacja jest właściwsza. Oznacza to, że przed przystąpieniem do nagry-

13 I. Kunicki, Ustawa o kosztach komorniczych. Komentarz, Warszawa 2018, s. 88.

14 Ibidem, s. 88. 
wania czynności w miejscu zamieszkania dłużnika lub osoby trzeciej komornik poucza obecnych zarówno o możliwości sprzeciwienia się utrwalaniu przebiegu czynności, jak i o możliwości zgłoszenia żądania podjęcia utrwalania czynności na nowo ${ }^{15}$. W rezultacie chodzi o dwa pouczenia, które komornik łącznie udziela wspomnianym osobom przed rozpoczęciem nagrywania czynności ${ }^{16}$.

Jeżeli dłużnik lub osoba trzecia sprzeciwią się utrwalaniu przebiegu czynności za pomocą urządzenia rejestrującego obraz i dźwięk przed rozpoczęciem tego utrwalania, komornik nie przystępuje do nagrywania. W tym wypadku komornik stwierdza czynność egzekucyjną protokołem, który powinien zawierać oznaczenie miejsca i czasu czynności, imiona i nazwiska stron oraz innych osób uczestniczących w czynności, sprawozdanie z przebiegu czynności, wnioski i oświadczenia obecnych, wzmiankę o odczytaniu protokołu, podpisy obecnych lub wzmiankę o przyczynie braku podpisu i podpis komornika. Chodzi bowiem o to, aby nie tylko sama czynność, ale i miejsce jej dokonywania będące miejscem zamieszkania dłużnika lub osoby trzeciej, nie zostało utrwalone i aby nagranie nie mogło być przekazane innym uczestnikom postępowania egzekucyjnego.

Jeżeli jednak sprzeciw dłużnika bądź osoby trzeciej zostanie wyrażony już po rozpoczęciu nagrywania, to komornik z mocy art. $809^{1} \S 3$ zd. 2 k.p.c. przerywa utrwalanie przebiegu czynności i sporządza protokół zgodnie z art. 809 k.p.c. Należy podkreślić, że sprzeciw zgłoszony w trakcie utrwalania przebiegu czynności ma skutki ex nunc, dlatego część nagrania dokonana przed sprzeciwem dłużnika lub osoby trzeciej pozostaje w mocy i stanowi utrwalenie przebiegu czynności. Do chwili zgłoszenia sprzeciwu protokół z czynności ma formę (wersję) skróconą (ze zwięzłym sprawozdaniem z przebiegu czynności; por. art. $809^{1}$ $\S 4$ k.p.c.), a po przerwaniu utrwalania przebiegu czynności za pomocą urządzenia rejestrującego obraz i dźwięk komornik stwierdza dalszy przebieg tej czynności protokołem sporządzonym na podstawie art. 809 k.p.c. To będzie jeden protokół, ale w dwóch formach — skróconej (do chwili sprzeciwu) i pełnej (od momentu zaprzestania utrwalania).

15 Por. też J. Jagieła, Nowe zasady egzekucyjnego zajęcia ruchomości, [w:] Sądowe postępowanie egzekucyjne. Nowe wyzwania i perspektywy, red. J. Jagieła, Warszawa 2020, s. 80-81; O. Marcewicz, Uwagi do art. 809, [w:] Kodeks postepowania cywilnego. Komentarz aktualizowany, t. 2. Art. 730-1217, Warszawa 2019. Zdaniem A. Jarochy pouczenia, o których mowa, będą najpewniej udzielane ad hoc, w czasie dokonywania czynności egzekucyjnych. Jednocześnie autor ten wyraził postulat dążenia do wypracowania sformalizowanej i znormalizowanej co do treści klauzuli pouczeniowej, która w formie pisemnej będzie wręczana przez komornika obecnym przy czynności uprawnionym podmiotom (dłużnikowi i wierzycielowi) przed przystąpieniem do czynności, zob. A. Jarocha, Obowiazek komornika sąowego $w$ zakresie udzielania pouczeń, w kontekście zmian Kodeksu postepowania cywilnego dokonanych ustawa o komornikach sadowych, [w:] Komornicy sądowi i egzekucja w nowej rzeczywistości prawnej, red. R. Kulski, Sopot 2019, s. 262.

${ }_{16}$ Nieco inaczej postrzega tę kwestię T. Łochowski (op. cit., uwaga $\mathrm{nr} 4$ do art. 809¹), który twierdzi, że sprzeciw jest wiążący dla komornika, co oznacza, że po jego zgłoszeniu komornik powinien zaniechać utrwalania czynności i pouczyć osobę zgłaszającą sprzeciw o możliwości zażądania ponownego nagrywania czynności. 
Dłużnik może sprzeciwić się utrwalaniu przebiegu czynności przez komornika tylko, jeśli czynność jest dokonywana w jego miejscu zamieszkania, a nie w miejscu zamieszkania osoby trzeciej. Również osoba trzecia może sprzeciwić się utrwalaniu przebiegu czynności za pomocą urządzenia rejestrującego obraz i dźwięk jedynie wówczas, gdy czynność jest dokonywana przez komornika w jej miejscu zamieszkania. W konsekwencji należy stwierdzić, że tylko ta osoba może zgłosić sprzeciw wobec utrwalania przebiegu czynności, w której miejscu zamieszkania czynność jest dokonywana. Przez miejsce zamieszkania, o którym mowa w art. $809^{1} \S 3$ k.p.c., należy rozumieć miejsce, w którym dłużnik lub osoba trzecia przebywa z zamiarem stałego pobytu (art. 25 k.c.), przy czym miejsce to należy raczej utożsamiać z lokalem mieszkalnym bądź budynkiem mieszkalnym. Ani dłużnik, ani osoba trzecia nie mogą sprzeciwić się utrwalaniu przebiegu czynności dokonywanej w innym miejscu niż miejsce zamieszkania, na przykład w miejscu prowadzenia działalności gospodarczej. W związku z tą okolicznością powstaje problem, czy utrwalaniu przebiegu czynności może sprzeciwić się wierzyciel, w którego miejscu zamieszkania jest dokonywana czynność (na przykład zajęcie ruchomości). Gdyby ściśle stosować przepis art. $809^{1} \S 3$ zd. 2 k.p.c., należałoby przyjąć, że możliwość zgłoszenia sprzeciwu mają jedynie dłużnik i osoba trzecia. Jeśli jednak spojrzymy na konstrukcję tego przepisu, w którym chodzi o zapewnienie (poszanowanie) prywatności osobom uczestniczącym w postępowaniu egzekucyjnym, należy uznać, że również wierzyciel może sprzeciwić się nagraniu czynności przez komornika w miejscu swojego zamieszkania ${ }^{17}$.

Sprzeciw zgłoszony w trybie art. $809^{1} \S 3$ k.p.c. jest wiążący dla komornika. Jeśli dłużnik lub osoba trzecia sprzeciwią się utrwalaniu przebiegu czynności, dla jej przerwania nie ma znaczenia żądanie nagrywania czynności wyrażone przez wierzyciela. W tym wypadku interes wierzyciela jest zabezpieczony stwierdzeniem czynności protokołem w formie pełnej (art. 809 k.p.c.).

Przejdźmy teraz do kwestii wpływu usterki technicznej (problemów technicznych) urządzenia rejestrującego obraz i dźwięk na utrwalanie przebiegu czynności w trybie art. $809^{1}$ k.p.c.

Jeżeli usterka uniemożliwiająca nagrywanie czynności wystąpi przed rozpoczęciem utrwalania, komornik powinien odwołać dokonywanie tej czynności i wyznaczyć ją na nowo.

Kwestia oddziaływania usterki technicznej urządzenia, która pojawiła się w trakcie utrwalania przebiegu czynności, wymaga poczynienia uwagi wstępnej. Należy wyraźnie rozróżnić dokonanie czynności i utrwalanie przebiegu jej dokonywania. Jeśli więc usterka techniczna urządzenia wystąpi w toku nagrywania czynności, należy tę czynność kontynuować i dokończyć. Wówczas komornik powinien zmienić stwierdzanie czynności protokołem skróconym z art. $809^{1} \S 4$

17 Za możliwością sprzeciwienia się utrwalaniu przebiegu czynności przez wierzyciela, w którego miejscu zamieszkania jest dokonywana ta czynność, opowiedział się również J. Jagieła (op. cit., s. 81). 
k.p.c. na jej stwierdzenie protokołem pełnym z art. 809 k.p.c. Podobnie jak w razie zgłoszenia sprzeciwu powstanie jeden protokół stwierdzający czynność, ale w dwóch formach (skróconej i pełnej).

W wypadku, w którym po dokonaniu czynności okaże się, że utrwalenie jej przebiegu z jakiegoś powodu nie nastąpiło, nie powtarza się czynności. Czynność ta została już dokonana, tyko jej przebieg nie został utrwalony.

Zgodnie z art. $809^{1} \S 5$ k.p.c. komornik umożliwia stronom i uczestnikom postępowania zapoznanie się z zapisem obrazu i dźwięku w siedzibie kancelarii komorniczej. Stronom ani uczestnikom postępowania nie wydaje się zapisu obrazu i dźwięku. Przepis art. $809^{1} \S 5$ k.p.c. jest lex specialis względem art. 9 $\S 2$ k.p.c. stanowiącego, że strony i uczestnicy mają prawo do otrzymania $\mathrm{z}$ akt zapisu dźwięku albo obrazu i dźwięku. Uzyskaniu zapisu obrazu i dźwięku przez strony i innych uczestników postępowania poprzez sporządzenie kopii nagrania ma zapobiegać również regulacja wspomnianego wcześniej rozporządzenia. Według $\S 8$ rozp. z.o.dź. zapis udostępnia się stronom i uczestnikom postępowania wyłącznie przez jego prezentację na urządzeniach odtwarzających obraz i dźwięk, które należą do komornika. W razie zapoznawania się z aktami sprawy w sądzie zapis udostępnia się wyłącznie w budynku sądu przez jego prezentację na urządzeniach odtwarzających obraz i dźwięk, które stanowią wyposażenie sądu. Natomiast udostępnienie zapisu organom nadzoru judykacyjnego lub administracyjnego oraz innym uprawnionym organom odbywa się za pośrednictwem konta w systemie teleinformatycznym, w którym są prowadzone akta sprawy, albo na informatycznym nośniku danych ( 99 rozp. z.o.dź.).

Należy również odnieść się do nagrywania ,prywatnego”. Nic nie stoi na przeszkodzie, żeby strony i uczestnicy postępowania utrwalali przebieg czynności - zarówno egzekucyjnych, jak i nieegzekucyjnych — we własnym zakresie (zob. art. $9^{1}$ k.p.c.). Dopuszczalne jest więc utrwalanie przez uczestników postępowania egzekucyjnego przebiegu czynności, przy których są obecni, bez konieczności uzyskania zezwolenia organu egzekucyjnego. Wypada zaznaczyć, że utrwalanie przebiegu czynności przez uczestników postępowania jest możliwe wyłącznie za pomocą urządzenia rejestrującego dźwięk. Nagranie to ma charakter prywatny, nie pełni funkcji procesowej i nie może konkurować z utrwaleniem (zapisem) dokonanym w trybie art. $809^{1}$ k.p.c.

Po przeprowadzonej analizie zasadniczych aspektów utrwalania przebiegu czynności komornika w trybie art. $809^{1}$ k.p.c. należy teraz ocenić, czy w wypadku naruszenia przepisów o utrwalaniu przebiegu takich czynności w rachubę wchodzi przewinienie dyscyplinarne z art. 222 pkt 11 u.k.s. polegające na rażącej lub uporczywej obrazie przepisów prawa.

Przepis art. 25 ust. 1 u.k.s. reguluje obowiązek działania komornika, jako funkcjonariusza publicznego, na podstawie i w granicach prawa. W świetle tego przepisu komornik jest obowiązany postępować zgodnie z przepisami prawa, orzeczeniami sądu, zarządzeniami lub zaleceniami uprawnionych organów nadzo- 
ru administracyjnego, złożonym ślubowaniem i zasadami etyki zawodowej. Jeśli komornik działa w sposób sprzeczny z przepisami prawa, narusza spoczywający na nim szczególny obowiązek i może narazić się na odpowiedzialność dyscyplinarną. Nie każde jednak naruszenie przepisów prawa przez komornika spowoduje, że będzie on odpowiadał dyscyplinarnie za przewinienie, o którym mowa $\mathrm{w}$ art. 222 pkt 11 u.k.s.

O ustaleniu, że doszło do naruszenia przepisów prawa o utrwalaniu przebiegu czynności i jednocześnie do popełnienia przez komornika przewinienia dyscyplinarnego zdecyduje zakwalifikowanie tego naruszenia jako rażącej lub uporczywej obrazy przepisów prawa. Ustawa nie precyzuje pojęcia rażącej, ani uporczywej obrazy.

„Rażąca" obraza przepisów prawa zakłada uwzględnienie charakteru tego naruszenia, jego ,jakości”, która świadczy o powadze uchybienia ${ }^{18}$. O „rażącym” naruszeniu prawa można mówić wtedy, gdy obraza jego przepisów ma nie tylko wyraźny (oczywisty) charakter, ale również odpowiednio wysoki ciężar gatunkowy. Według Sądu Najwyższego naruszenie prawa o rażącym charakterze występuje przede wszystkim wówczas, gdy treść rozstrzygnięcia pozostaje w wyraźnej i oczywistej sprzeczności z treścią przepisów prawa i gdy charakter tego naruszenia powoduje, że rozstrzygnięcie nie może być zaakceptowane jako akt wydany przez organ praworządnego państwa ${ }^{19}$. Natomiast $\mathrm{z}$, uporczywą" obrazą przepisów prawa mamy do czynienia, jeśli naruszenie prawa ma mniejszy ciężar gatunkowy, lecz obejmuje wielokrotne uchybienia i zachowanie o charakterze trwałym ${ }^{20}$.

Mając na uwadze zaprezentowane znaczenia sformułowania „rażąca lub uporczywa obraza", a także jego nieostry charakter, należy stwierdzić, że jednoznaczna ocena, czy w wypadku naruszenia przez komornika omówionej wcześniej regulacji o utrwalaniu przebiegu czynności mamy do czynienia z taką obrazą prawa, którą da się zakwalifikować jako przewinienie dyscyplinarne z art. 222 pkt 11 u.k.s., musi być dokonywana z uwzględnieniem całokształtu okoliczności konkretnej sprawy. Daje temu również wyraz orzecznictwo, które wyjaśnia i precyzuje pojęcie „rażącej” obrazy prawa na gruncie i dla potrzeb określonych stanów faktycznych ${ }^{21}$. Dokonując tej oceny in casu, należy uwzględnić skutki obrazy

18 M. Świeczkowska-Wójcikowska, op. cit., uwaga nr 23 do art. 222.

19 Wyrok Sądu Najwyższego z dnia 20 czerwca 1995 roku, III ARN 22/95, OSNP 1995/24/297.

20 B. Falkowski, [w:] Komentarz do ustawy o komornikach sądowych, red. M. Simbierowicz, M. Świtkowski, Warszawa 2019, uwaga nr 13 do art. 222; M. Świeczkowska-Wójcikowska, op. cit., a także postanowienie Sądu Apelacyjnego w Krakowie z dnia 13 grudnia 2000 roku, II AKz 289/00, LEX.

21 Przykładowo w wyroku z dnia 11 października 1994 roku, I PO 11/94, OSNP 1995/4/57, Sąd Najwyższy stwierdził, że pojęcie rażącego naruszenia prawa należy do tak zwanych zwrotów niedookreślonych, co powoduje, że w każdym konkretnym przypadku do sądu należy stwierdzenie, czy mamy do czynienia z tego rodzaju kwalifikowanym naruszeniem prawa, czy też nie. Na gruncie postępowania dyscyplinarnego prowadzonego przeciwko sędziemu, Sąd Najwyższy może stwierdzić, że o tym, czy obraza przez sędziego przepisów prawa w toku postępowania jest rażąca, decydują jej negatywne skutki, godzące w interesy uczestników postępowania lub innych podmio- 
przepisów o nagrywaniu czynności komornika ${ }^{22}$, a także wziąć pod uwagę ratio regulacji o utrwalaniu przebiegu czynności. Jak wskazano w uzasadnieniu projektu nowelizacji, celem tego przepisu jest zapewnienie sądowi i stronom kontroli nad czynnościami, przy których dochodziło do sytuacji konfliktowych oraz występowało najwięcej przypadków rażącego naruszenia prawa, na przykład przez bezzasadne odjęcie dozoru nad zajętymi ruchomościami lub przez zajęcie ruchomości ewidentnie nienależących do dłużnika ${ }^{23}$. Należy przy tym zaznaczyć, że nagrywanie przebiegu czynności może również posłużyć komornikowi do obrony przed nieuzasadnionymi zarzutami kierowanymi pod jego adresem, w szczególności ze strony dłużnika ${ }^{24}$.

Generalnie rzecz ujmując, nie wydaje się, żeby naruszenie przez komornika przepisów o utrwalaniu przebiegu czynności dokonywanej z jego udziałem stanowiło rażącą obrazę przepisów prawa z art. 222 pkt 11 u.k.s. Jeżeli do naruszenia przepisów o utrwalaniu przebiegu czynności będzie dochodzić wielokrotnie, przez dłuższy okres czasu, z nastawieniem złej woli nieprzestrzegania tych przepisów, nie można jednak wykluczyć przypisania komornikowi uporczywej obrazy prawa. Warto również odnotować, że obraza analizowanej regulacji może jednocześnie naruszać prawo do prywatności uczestników danej czynności (art. 24 k.c.) lub prawo do ich wizerunku (art. 81-83 ustawa - Prawo autorskie).

\section{INFRINGEMENT OF REGULATIONS ON RECORDING OPERATIONS OF A JUDICIAL OFFICER AS A DISCIPLINARY OFFENCE}

\section{Summary}

The paper first analyzes the important aspects of recording the hearing of the judicial officer's operation with the use of an audio/video recording device (art. $809^{1}$ of the Civil Procedure Code). An assessment was then made as to whether infringement of the regulations on recording the operations of a judicial officer constitutes a disciplinary offence. According to art. 222 point 11 Act of Judicial Officers the judicial officer is disciplinarily liable for gross or persistent violation of law other than those mentioned in this provision. This assessment must be made taking into account all the circumstances of the specific case. Generally speaking, it does not seem that the infringement by the judicial officer of the regulations on recording the operations performed with his participation constitutes a gross offence against the provisions of the law. However, it cannot be ruled out that

tów albo wymiaru sprawiedliwości - oceniane zawsze na tle konkretnych okoliczności (wyrok Sądu Najwyższego z dnia 10 stycznia 2013 roku, II K 32/09, LEX).

22 Jak zaznaczył Sąd Najwyższy w wyroku z dnia 27 czerwca 2002 roku, SNO 18/02, LEX, popełniony błąd musi też narażać na szwank prawa i istotne interesy stron (innych osób biorących udział w postępowaniu) albo powodować szkodę.

${ }^{23}$ Uzasadnienie rządowego projektu ustawy o komornikach sądowych, druk nr 1582 Sejmu VIII kadencji, s. 44.

${ }^{24}$ M. Muliński, op. cit., s. 1526. 
the judicial officer will be assigned a persistent offence of the law, if the violation of the provisions on the recording of the operations will occur repeatedly, for a longer period of time, with the judicial officer's attitude of ill will to non-compliance with these provisions.

Keywords: recording the hearing of the judicial officer's operation, a disciplinary offence, gross violation of law, an audio/video recording device

\section{BIBLIOGRAFIA}

Dziewulska M., [w:] Ustawa o komornikach sądowych. Komentarz, red. G. Sikorski, Sopot 2019.

Dzienis P., [w:] Ustawa o komornikach sadowych. Ustawa o kosztach komorniczych. Komentarz, red. R. Reiwer, Warszawa 2019.

Falkowski B., [w:] Komentarz do ustawy o komornikach sadowych, red. M. Simbierowicz, M. Świtkowski, Warszawa 2019.

Jagieła J., Nowe zasady egzekucyjnego zajęcia ruchomości, [w:] Sądowe postępowanie egzekucyjne. Nowe wyzwania i perspektywy, red. J. Jagieła, Warszawa 2020.

Jagieła J., Odpowiedzialność dyscyplinarna komorników, asesorów i aplikantów komorniczych, [w:] Założenia projektu nowej ustawy o komornikach sadowych, red. A. Marciniak, Sopot 2013.

Jarocha A., Obowiązek komornika sądowego w zakresie udzielania pouczeń, w kontekście zmian Kodeksu postepowania cywilnego dokonanych ustawa o komornikach sadowych, [w:] Komornicy sądowi i egzekucja w nowej rzeczywistości prawnej, red. R. Kulski, Sopot 2019.

Klonowski M., [w:] Ustawa o komornikach sadowych. Ustawa o kosztach komorniczych. Komentarz, red. R. Reiwer, Warszawa 2019.

Kunicki I., Ustawa o kosztach komorniczych. Komentarz, Warszawa 2018.

Laskowska-Hulisz A., Wydatki komornika sq̨dowego i zasady ich ustalania w świetle ustawy o kosztach komorniczych, [w:] Komornicy sadowi i egzekucja w nowej rzeczywistości prawnej, red. R. Kulski, Sopot 2019.

Łochowski M., [w:] Kodeks postępowania cywilnego. Komentarz, red. T. Szanciło, t. 2, Warszawa 2019.

Marcewicz O., Uwagi do art. 809, [w:] Kodeks postepowania cywilnego. Komentarz aktualizowany, red. A. Jakubecki, t. 2. Art. 730-1217, Warszawa 2019.

Marciniak A., Sadowe postępowanie egzekucyjne w sprawach cywilnych, Warszawa 2019.

Muliński M., [w:] Kodeks postępowania cywilnego. Komentarz do zmian, red. T. Zembrzuski, t. 2, Warszawa 2020.

Rączka P., Odpowiedzialność dyscyplinarna komornika sądowego, „Przegląd Prawa Egzekucyjnego" 2006, nr 12.

Szereda A.J., Egzekucja z nieruchomości po zmianach wprowadzonych ustawa o komornikach sqdowych, [w:] Analiza i ocena ustawy o komornikach sadowych oraz ustawy o kosztach komorniczych, red. A. Marciniak, Sopot 2018.

Świeczkowska-Wójcikowska M., [w:] Ustawa o komornikach sądowych. Ustawa o kosztach komorniczych. Kodeks Etyki Zawodowej Komornika Sadowego. Komentarz, red. M. Świeczkowska-Wójcikowska, J. Świeczkowski, Warszawa 2020. 